DOI https://doi.org/10.36059/978-966-397-159-9/89-108

\title{
TOPICAL DIRECTIONS FOR IMPROVEMENT OF INFORMATION RELATIONS IN ACTIVITIES OF THE STATE BORDER GUARD SERVICE OF UKRAINE
}

\section{Iryna Kushnir}

\section{INTRODUCTION}

Ukraine's aspiration to join the European Union needs to adapt national legislation to the legislation of the European Union and requires the state authorities to take decisive steps to achieve a new, qualitative and appropriate level of development. One of these directions for development is the system of state border protection, which needs to bring the principles, forms and methods of state border protection, border control procedures in line with generally accepted norms of the European Union. The issues related to the development of the state border protection system are quite important and urgent due to not only the external (international) factors but to the internal ones as well. In the modern context, the legal status of the State Border Guard Service of Ukraine (SBGS) and the departmental priorities (improving the effectiveness of state policy implementation in the field of state border security ${ }^{1}$ ) are at a stage of development, which is caused by the change of threats at the state border and require decisive legal steps and the most optimal ones are introduced in European countries ${ }^{2}$.

The constant change in the nature of threats at the state border of Ukraine requires adequate response, as the consequence of the activities of the SBGS is the appropriate national security level (security of the nation, society and individual citizen) in terms of inviolability of the state border of Ukraine, preventing the change of the border line and realization of the right of unimpeded crossing of the state border of Ukraine ${ }^{3}$. Border security as a

\footnotetext{
${ }^{1}$ Main Directions of Activities and Further Development of SBGS of Ukraine in 2019. URL: dpsu.gov.ua/upload/Haprjami_ДПСУ_Optimized.pdf. (accessed 11 October 2019).

${ }^{2}$ Kaliuzhnyi R. A., Kushnir I. P. (2015) Pravove zabezpechennja vzajemodiji publichnoji administraciji u prykordonnij sferi [Legal Support for Public Administration Interaction in the Sphere of Border Guarding]. Kyiv: "MP Lesia”. p. 159. (in Ukrainian).

${ }^{3}$ Liashuk R. M., Kushnir I. P. (2017) Rezuljtatyvnistj ta efektyvnistj $v$ dijaljnosti orghaniv okhorony derzhavnogho kordonu Ukrajiny [Effectiveness and Efficiency in Activities of the State Border Protection Bodies of Ukraine]. Law and Society, No. 5, p. 158. (in Ukrainian).
} 
component of national security is provided by a set of various measures and provides for the protection of the interests of the individual, society and state in this field ${ }^{4}$. An element of modern border security is its information component with information relations being one of its dimensions.

The intensive development of the information society, the total informatization of the public and private sphere, the introduction of electronic means for identification of personality, taking into account the European integration, require the SBGS to continuously improve its information activities. With this in mind, it is worth mentioning the consideration of Yu. Ye. Maksymenko, who states that the information branch of legislation is the most dynamic in relation to other branches of legislation, and the intensity of changes in the information sphere contributes to the need for special attention of the scientific community to the study of the current information legislation, the state of information relations in Ukraine $^{5}$.

Information relations, which are conditioned both by the internal organizational aspects of the information activities of the SBGS and the provision of information rights of citizens (within the competence), require timely coverage and regulation by legal acts, the creation and improvement of clear organizational mechanisms for information support and the adequate state of information security. The issue of improving information relations in the field of SBGS activities is closely related to the expected result, final impact and their impact on the state of border security.

The need for continuous development of border security, the introduction of European standards for integrated border management, improvement of confidence in the SBGS, intensive development of information society (emergence of new formats of information communication), as well as the necessity of confronting hybrid (information) war, determine the relevance of information relations development in the SBGS activities.

\section{Substantiation of necessity to develop norms of information legislation}

Actual fundamentals for improving information relations in the SBGS activities are formulated in the regulatory requirements of information society development at the state and departmental levels, substantiated in

\footnotetext{
${ }^{4}$ Kushnir I. P. (2018) Analiz zmistu ponjattja «bezpeka derzhavnogho kordonu» [Content Analysis of "State Border Security" Concept]. Bulletin of the Southern Regional Centre of the National Academy of Law Sciences of Ukraine,. No. 16, p. 78. (in Ukrainian).

5 Maksymenko Yu. Ye. (2014) Normatyvno-pravove reghuljuvannja informacijnykh vidnosyn v Ukrajini: stan ta perspektyvy [Legal Regulation of Information Relations in Ukraine: Status and Prospects]. Legal Bulletin, No. 3, p. 142. (in Ukrainian).
} 
programmes, plans, strategies, concepts oriented on the development of the national and state security system, observance of citizens' rights, compliance with the requirements of Ukrainian and international information society.

Increasing the role of information, developing the forms of its display and application (electronic communication, improving the use of information and telecommunication systems, the use of electronic qualified signatures, electronic identification) in the activities of the SBGS enable to emphasize the relevance and the need for quality regulatory and legal support of informational relations in the sphere of border guarding. It should be built on a systematic basis that will help to achieve the desired goal - a stable state of security of Ukraine's state borders.

The main coordinates for the development of information relations are laid down in the planning documents designed for a certain period, taking into account the European guidelines. Thus, the Plan of Measures to Implement the National Strategic Course for Acquiring Full Membership of Ukraine in the European Union and in the North Atlantic Treaty Organization, approved by Presidential Decree No 155/2019 of April 20, 2019, provides for the implementation of effective information policy in the fields of European and North Atlantic integration of Ukraine and expand of cooperation with the EU on information security and cyber-security, ensuring the resistance of critical infrastructure, countering transnational crime, enhancing border security, and minimizing the risks in the sphere of migration ${ }^{6}$.

In the direction of ensuring information security of the state in the current context, the Doctrine of Information Security formulates the priorities of the state policy in the information sphere, in particular, the relevant ones for the sphere of border guarding are: creation of an integrated system for information threats assessment and prompt response to them ${ }^{7}$. Development of the risk analysis system in the SBGS of Ukraine started in $2006^{8}$, and improvements are still underway today; improvement of the SBGS authority in order to achieve an adequate level of capabilities to

${ }^{6}$ Plan of Measures for Realization of the Strategic Course of the State to Acquire Full Membership of Ukraine in the European Union and in the North Atlantic Treaty Organization: by Presidential Decree No. 155/2019 of April 20, 2019. art. 15, 17. URL: https://www.president.gov.ua/documents/1552019-26586. (accessed 18 October 2019).

${ }^{7}$ On the decision of the National Security and Defence Council of Ukraine of December 29, 2016 "On the Doctrine of Information Security of Ukraine": Presidential Decree of February 25, 2017 No. 47/2017. art. 5. Official Bulletin of the President of Ukraine. 2017. No. 5. Art. 102.

${ }^{8}$ Development of the system of risk analysis in the State Border Guard Service of September 19, 2017. URL : http://dpsu.gov.ua/ua/rozvitok-sistemi-analizu-rizikivderzhprikordonsluzhbi-/. (accessed 4 October 2019). 
respond to real and potential threats to Ukraine's national interests in the border information sphere; legislative regulation of the mechanism for revealing, fixing, blocking and removing information that promotes war or violation of the territorial integrity of Ukraine, threatens state sovereignty from the information space of the state; development and protection of technological infrastructure to provide border information security of Ukraine; provision of full coverage of the territory of Ukraine with digital broadcasting, especially in the border areas, as well as temporarily occupied territories; intensification of counteraction to special information operations aimed at violating sovereignty and territorial integrity, undermining Ukraine's defence capability, demoralizing the SBGS personnel, escalating social and political situation, in particular, in border areas; prevention of free circulation of information products (printed and electronic), primarily originating from the territory of the aggressor state, containing propaganda of war, national and religious enmity, changing the constitutional order by force or violating Ukraine's sovereignty and territorial integrity, provoking mass disturbances. Control over importation of such printed products in Ukraine is carried at border crossing points ${ }^{9}$ or entry exit check points while entering the temporarily occupied territory and leaving it by relevant SBGS units $^{10}$; conduct of actions by intelligence agencies of Ukraine in order to promote and protect national interests of Ukraine in the information sphere, to counteract external threats to the information security of the state outside Ukraine ${ }^{11}$. The SBGS carries out operational and investigation activities independently, serving the interests of state border security, and in the process of conducting intelligence activities it should contribute to the realization and protection of national interests of Ukraine in the information sphere, counteract the external threats to the information security of the state $^{12}$.

9 "On Border Control": Law of Ukraine of November 5, 2009. Bulletin of the Verkhovna Rada of Ukraine. 2010. No. 6. Art. 46.

${ }^{10}$ On Approval of the Procedure for Entering and Leaving Temporarily Occupied Territory of Ukraine (as amended): Resolution of the Cabinet of Ministers of Ukraine of June 4, 2015. No. 367. URL: http://zakon5.rada.gov.ua/laws/show/367-2015-\%D0\%BF. (accessed 20 October 2019).

${ }^{11}$ On the decision of the National Security and Defence Council of Ukraine of December 29, 2016 "On the Doctrine of Information Security of Ukraine": Presidential Decree of February 25, 2017 No. 47/2017. art. 5. Official Bulletin of the President of Ukraine. 2017. No. 5. Art. 102.

${ }^{12}$ On the decision of the National Security and Defence Council of Ukraine of December 29, 2016 "On the Doctrine of Information Security of Ukraine": Presidential Decree of February 25, 2017 No. 47/2017. art. 6. Official Bulletin of the President of Ukraine. 2017. No. 5. Art. 102. 
Creation of conditions for the safe functioning of cyberspace; its use for the benefit of individual, society and the state is provided for by the Strategy of Cybersecurity of Ukraine ${ }^{13}$.

The lack of systematic planning for the development of information society and information security is a significant drawback at the present stage of information relations development. Back in 2014, the Verkhovna Rada of Ukraine adopted a resolution "On Recommendations of Parliamentary Hearings on: "Legislative Support for the Development of Information Society in Ukraine"" in which the Cabinet of Ministers of Ukraine obliged to develop a program for the development of the information society in Ukraine for 20162020. In this regard, the Department of Information Policy developed a draft Strategy for the Development of Information Space of Ukraine for the Period up to 2020; its main purpose was to create the political, economic, organizational and logistical conditions for the development of the national information space of Ukraine, and also to develop a modern model of state information policy, to ensuring the development and protection of the national information space ${ }^{14}$. But that draft has not been signed and appropriately implemented in public relations, so at the state level there is a fragmentary settlement of certain issues of information relations in the aspect of information security, cyber security, etc.

Within the specific activities of the SBGS and ensuring the protection of the state border of Ukraine, there are also decisive normative acts, which direct the development of the border guard agency, taking into account the existing threats and needs of the sphere of border guarding, as well as formulate specific tasks for particular directions of information relations. These include the decrees of the Cabinet of Ministers of Ukraine, the Strategy for Development of the State Border Guard Service of Ukraine (hereinafter referred to as the Strategy), the Strategy for Integrated Border Management for the Period up to 2025, Decisions of the SBGS Board (specifying specific tasks for the development of information component for a certain period). The provisions of these documents define and specify the directions of information and legal activities of the SBGS within the limits defined by the legislation, taking into account threats in the field of state border protection, integration processes and improvement of its information

\footnotetext{
${ }^{13}$ Cyber Security Strategy of Ukraine: Presidential Decree No. 96/2016 of March 15, 2016. Uriadovyi Kurier. 2016. No. 52.

${ }^{14}$ Draft Decree of the President of Ukraine on Approval of the Strategy for the Development of Information Space of Ukraine for the Period up to 2020. URL : http://comin.kmu.gov.ua/control/uk/publish/article?art_id=113102\&cat_id=61025. (accessed 12 October 2019).
} 
component. Such provisions can be called program documents in the field of information relations of the $\mathrm{SBGS}^{15}$.

The Strategy declares that in the direction of the information component development of the state border protection system, it is planned to improve the system of analysis and evaluation of information, as well as to upgrade the system of communication, informatization and protection of information through: bringing mechanisms for the accumulation, processing, evaluation and analysis of information in line with European standards; improving the system of risk analysis, introducing modern technologies for carrying out a consistent multidimensional assessment of the situation at the state border, forecasting its development at all levels of management; developing existing mechanisms for the exchange of open statistical and analytical information between subjects of integrated border management and border guard authorities of the Member States of the European Union, as well as international organizations and institutions; modernizing the system for processing information about persons crossing the state border, their travel documents using electronic media, including the biometric control function; improving the components of the integrated information and telecommunication system "Hart" and upgrading the integrated interagency information and telecommunication system "Arkan" regarding the control of persons, vehicles and goods crossing the state border; deploying mobile automated workstations with access to databases, a modern video surveillance system, a special telecommunication system in the state border guard bodies; introducing an electronic document circulation system using electronic digital signature, modern complexes for cryptographic protection of information, the latest means for special communication on mobile objects, and mechanisms for cyber-security in information and telecommunication systems ${ }^{16}$.

Taking this into consideration, it should be noted that the interdepartmental provision of information relations in the SBGS is based on the basic requirements of legislative acts, involves the introduction and use of modern tools and methods for processing, transmission, analysis, storage of information, comprehensive information exchange, which are focused on improvement of information-oriented provision of inter-agency activities of

${ }^{15}$ Kushnir I. P. (2018) Informacijno-pravova dijaljnistj Derzhavnoji prykordonnoji sluzhby Ukrajiny: normatyvno-pravovyj aspekt [Information and Legal Activities of the State Border Guard Service of Ukraine: Regulatory Aspect]. Constitutional and Legal Academic Studies, No. 2, p. 168. (in Ukrainian).

${ }^{16}$ On Approval of the State Border Guard Service Development Strategy: Decree of the Cabinet of Ministers of Ukraine of November 23, 2015. No. 1189-r. Uriadovyi Kurier. 2015. No. 220 
the SBGS as a manager of information in the field of state border protection. But such measures are predominantly technical and organizational in nature and are mostly in the process of formation and development. In addition, at the national level, there are a number of negative aspects, which are caused by the lack of systematic regulation of information relations, which in a certain way affects the state of information relations in the SBGS activities, and require improvement accordingly.

The main cornerstone of normative legal regulation of information relations in the SBGS activities is the disorder of information legislation norms. This position is monitored in almost all scientific studies on the problems of information law, information relations, certain aspects of the subject-object composition of these relations. The necessity to improve information law is driven by real needs, namely: recent adoption of a large body of information legislation that is sometimes inconsistent or even controversial; rapid development of the information society, information technologies which mechanisms do not keep up with the conditions of time; stay of information law (as a complex, cross-sectoral branch of law, as a science) at the stage of formation and development.

V. O. Shepeta points out that the Ukrainian information legislation is difficult to recognize as effective, despite a rather large number of regulatory documents regulating information relations in the information sphere ${ }^{17}$.

The basic requirement of the information and legal doctrine is to systematise legislation on information issues. In the science of information law, such requirements are substantiated by the following reasons: unnecessary duplication; identification and elimination of gaps in legislation; reduction of timeframe for creating acts; improvement of their quality and efficiency of the norms included in them ${ }^{18}$; there are numerous normative and legal acts for regulation of information legal relations of different legal force; dynamic character of information relations; non-conformity with European Union standards; the declarative nature of individual norms due to the lack of a mechanism for right implementation; the need for a systematic solution to the problem of legal regulation of public relations in the field of

17 Shepeta V. O. (2012) Administratyvno-pravovi zasady tekhnichnogho zakhystu informaciji [Administrative and Legal Principles of Technical Protection of Information]. Kyiv: FOP O. P. Lipkan. p. 183. (in Ukrainian).

${ }^{18}$ Aristova I. V. (2000) Derzhavna informacijna polityka: orghanizacijno-pravovi aspekty [State Information Policy: Organizational and Legal Aspects]. Kharkiv: University of Internal Affairs. p. 174-179. (in Ukrainian). 
information security ${ }^{19}$; there are conflicts and competition of legal acts regulating legal relations in the information sphere; fragmentation and situational nature of right regulation; inconsistency of the conceptual and categorical apparatus (information terminology), which is fixed in normative and legal acts; multitude and ramified structure of legal acts, which complicates their enforcement and control over implementation; domination of by-laws over laws ${ }^{20}$; declarativity of information legislation norms without a mechanism and procedure for their implementation, which causes a significant number of offences; a number of banquet norms, abstract, subjective, technical concepts that need further official clarification or a clear attachment of definitions; lack of attachment for basic concepts ${ }^{21}$; there are conflicts and competition of legal acts regulating legal relations in the information sphere; fragmentation and situational nature of right regulation; inconsistency of the conceptual and categorical apparatus (information terminology), which is fixed in normative and legal acts; multitude and ramified structure of legal acts, which complicates their enforcement and control over implementation; inconsistency of some norms of information legislation adopted at different times; domination of by-laws over laws ${ }^{22}$; information law is lagging behind practice ${ }^{23}$.

This list of reasons should include the availability of departmental legal acts on regulation of information activities of the SBGS which are restricted for the general access, the state registration mechanism is not implemented in respect of certain acts, etc. These reasons prove the need to improve the legislation regulating information relations with sufficient substantiation and meets the basic principles of the theory of law and legislative process.

${ }^{19}$ Maksymenko Yu. Ye. (2007) Teoretyko-pravovi zasady zabezpechennja informacijnoji bezpeky Ukrajiny [Theoretical and Legal Principles for Ensuring Information Security of Ukraine]. Kyiv. p.146 .(in Ukrainian).

20 Shepeta V. O. (2012) Administratyvno-pravovi zasady tekhnichnogho zakhystu informaciji [Administrative and Legal Principles of Technical Protection of Information]. Kyiv: FOP O. P. Lipkan. p. 183. (in Ukrainian).

${ }^{21}$ Maksymenko Yu. Ye. (2014) Normatyvno-pravove reghuljuvannja informacijnykh vidnosyn v Ukrajini: stan ta perspektyvy [Legal Regulation of Information Relations in Ukraine: Status and Prospects]. Legal Bulletin, No. 3, pp. 144-145. (in Ukrainian).

${ }^{22}$ Lipkan V. A., Baskakov V. Yu. (2013) Administratyvno-pravovyj rezhym informaciji z obmezhenym dostupom v Ukrajini [Administrative and legal regime of sensitive information in Ukraine]. Kyiv: FOP O. P. Lipkan. pp. 164-165 (in Ukrainian).

${ }^{23}$ Kaliuzhnyi R. A., Kopan O. V., Martseniuk O. H. (2013) Teoretyko-metodologhichni zasady informacijnogho prava Ukrajiny: realizacija prava na informaciju [Theoretical and Methodological Principles of Information Law of Ukraine: Exercise of the Right to Information]. Kyiv: "MP Lesia". p. 181. (in Ukrainian). 
According to its nature the systematization process of normative legal acts involves their ordering, bringing into a certain harmonized system ${ }^{24}$.

\section{Improvement of information legislation norms}

A number of scientists R. A. Kaliuzhnyi, O. V. Kopan, O. H. Martseniuk, rightly affirm that the basis for systematization of information law norms should be worked out by legal science and proven by the fundamental principles: combination of traditions and innovations; incorporation of the norms of current information legislation of Ukraine into the new system through the aggregation of law institutions; formation of inter-branch institutions of law on the basis of relations with sectoral institutions ${ }^{25}$.

Information law means the system of laws of Ukraine, the current international agreements of Ukraine with the consent provided by the Verkhovna Rada of Ukraine, as well as the subordinate legal acts of Ukraine adopted in accordance with the Constitution of Ukraine governing public relations in the field of information ${ }^{26}$.

Taking into account the substantive elements (normative legal acts) during systematization, it is necessary to consider the normative acts (agreements, conventions) of international law ratified by Ukraine; to legalize positive practices in the field of information relations and norms of public morality, the universal human values defined by the United Nations in its Charter, the Declaration of Human Rights, European Union decisions and other generally accepted interstate normative acts being used as standards today, and which are used to define the civilization of not only a certain country but also the world community as a whole ${ }^{27}$.

In general, systematization of information legislation (systematization of laws and regulations about information) involves the purposeful activity of competent authorities or individuals in structuring, monitoring, researching,

${ }^{24}$ Krestovska N. M., Matvieieva L. H. (2015) Teorija derzhavy i prava. Pidruchnyk. Praktykum. Testy [The Theory of State and Law. Textbook. Case Study. Tests: textbook]. Kyiv: Yurinkom Inter. p. 384. (in Ukrainian).

${ }^{25}$ Kaliuzhnyi R. A., Kopan O. V., Martseniuk O. H. (2013) Teoretyko-metodologhichni zasady informacijnogho prava Ukrajiny: realizacija prava na informaciju [Theoretical and Methodological Principles of Information Law of Ukraine: Exercise of the Right to Information]. Kyiv: "MP Lesia". p. 182. (in Ukrainian).

${ }^{26}$ Lipkan V. A., Cherepovskyi K. P. (2014) Inkorporacija informacijnogho zakonodavstva Ukrajiny [Incorporation of Information Legislation of Ukraine]. Kyiv: FOP O. P. Lipkan. p. 134. (in Ukrainian).

${ }^{27}$ Kaliuzhnyi R. A., Kopan O. V., Martseniuk O. H. (2013) Teoretyko-metodologhichni zasady informacijnogho prava Ukrajiny: realizacija prava na informaciju [Theoretical and Methodological Principles of Information Law of Ukraine: Exercise of the Right to Information]. Kyiv: "MP Lesia". p. 183. (in Ukrainian). 
streamlining laws to improve the effectiveness of lawmaking, law enforcement and legal education concerning the information sphere of society $^{28}$.

At the first stage of improving information legislation, as noted by I. V. Aristov, it is necessary not to start immediately with its reformation, but develop a strategy for the formation of information legislation ${ }^{29}$.

For the most part, with regard to new branches, the subject of which has not yet been sufficiently defined, the most rational and adequate direction for improvement is to systematise regulatory legal material through incorporation and consolidation. The incorporation will play a function of accounting for regulatory legal materials, and consolidation should begin the process of further codification ${ }^{30}$.

V. A. Lipkan and K. P. Cherepovskyi believe that incorporation can be done according to institutional features reflected in the norms of the Constitution of Ukraine: where the term "information" and similar terms ("records", "messages", "data") are used, or information is part of categories (e.g. information security, environmental information, etc.), but other legislation is omitted in this approach, where information is the object of legal relationship ${ }^{31}$. There is a position regarding the use of structured information law institutions as criteria for incorporation ${ }^{32}$.

Unlike incorporation, consolidation involves the reworking of legal array, its unification, eliminates numerous regulatory acts, eliminates excessive fragmentation, helps to consolidate them and further implement codification.

Today, a significant number of scientists have developed draft Codes on the settlement of information relations (K. Bieliakov, M. Shvets and V. Bryzhko, H. Krasnostup, V. Lypkan, K. Cherepovskyi, V. Tsymbaliuk

${ }^{28}$ Lipkan V. A., Cherepovskyi K. P. (2014) Inkorporacija informacijnogho zakonodavstva Ukrajiny [Incorporation of Information Legislation of Ukraine]. Kyiv: FOP O. P. Lipkan. p. 140. (in Ukrainian).

${ }^{29}$ Aristova I. V. (2000) Derzhavna informacijna polityka: orghanizacijno-pravovi aspekty [State Information Policy: Organizational and Legal Aspects]. Kharkiv: University of Internal Affairs. p. 174. (in Ukrainian).

${ }^{30}$ Lipkan V. A., Zalizniak V. A. (2012) Systematyzacija informacijnogho zakonodavstva Ukrajiny [Systematization of Information Legislation of Ukraine]. Kyiv: FOP O. P. Lipkan. p. 178. (in Ukrainian).

${ }^{31}$ Lipkan V. A., Cherepovskyi K. P. (2014) Inkorporacija informacijnogho zakonodavstva Ukrajiny [Incorporation of Information Legislation of Ukraine]. Kyiv: FOP O. P. Lipkan. p. 169. (in Ukrainian).

${ }^{32}$ Shkarupa V., Tsymbaliuk V. (2006) Zastosuvannja polozhenj prava shhodo formuvannja osnov teoriji informacijnogho prava [Application of Legal Provisions to Form the Basis of Information Law Theory]. Legal Informatics. No. 3 (11). p. 46. (in Ukrainian). 
etc.) and presented to the public. There is also a draft Information Code developed by the State Committee on Information Policy, Television and Broadcasting of Ukraine.

Emphasizing the topicality of information relations in the modern world and in Ukraine, taking into account a number of problematic issues in the structure of drafts of such Information Codes, the requirements and standards of international law, the obligations of Ukraine regarding the process of its integration into the world community, as well as the sphere of legal regulation are taken into account ${ }^{33}$.

Carrying out systematization of information legislation will facilitate harmonization of its norms, improvement of conceptual and categorical apparatus, normalization of law enforcement activities in realization of information rights, information activities and, in general, establishment of level of relations in accordance with the requirements of modern information society. Regarding the peculiar activities of the SBGS, it is necessary to develop an Information Concept in the Sphere of Border Guarding.

Another direction for improving information relations is caused by the need to clarify the terminology and content of certain categories in the rules of information legislation. Only accurate and unambiguous terms and concepts will allow to most correctly formulate the content of a particular legal institution and ensure culture of legal regulation in a particular area of legal relations, as the production of standardized definitions in the law in general is one of the important tasks of lawmaking and overall legislative practice $^{34}$. In Ukraine, it is believed that the solution of problems of regulatory legal support of information relations is possible on the basis of situational response. Certain problems of legal regulation of public relations in this field are solved in separate laws and by-laws rather fragmentarily; a number of legal norms that directly or indirectly regulate public relations in the field of information and communication relations are not conceptually consistent $^{35}$. In this regard, O. A. Baronov notes that the work on the development of information law and the improvement of information

33 Bieliakov K. I. (2009) Orghanizacijno-pravove ta naukove zabezpechennja informatyzaciji v Ukrajini: problemy teoriji ta praktyky [Organizational, Legal and Scientific Support of Informatization in Ukraine: Problems of Theory and Practice]. Kyiv. p. 10. (in Ukrainian).

${ }^{34}$ Lytvyn N. A. (2018) Administratyvno-pravove zabezpechennja informacijnoji dijaljnosti orghaniv Derzhavnoji fiskaljnoji sluzhby Ukrajiny [Administrative and Legal Support of Information Activities of Bodies of the State Fiscal Service of Ukraine]. Irpin. p. 385. (in Ukrainian).

${ }^{35}$ Zhanhozha R. (2000) Do pytannja rozshyrennja informacijnogho prostoru Ukrajiny [On the Issue of Expansion of the Information Space of Ukraine]. Strategic Panorama. No. 3, pp. 203-206. p. 203 .(in Ukrainian). 
legislation has a significant prospect in view of the range and the importance of problems that occur in the information sphere ${ }^{36}$.

Lack of established terminology in the information legislation may cause refusal from the public administration to satisfy citizens' information rights, confusion in law enforcement activities, as well as subjectivism in addressing issues in the information sphere.

It is quite often that acting in their own interests or in the interests of third parties, officials refuse to give public information to citizens without reason, substituting categories that have not been clearly fixed in the current norms of information legislation, in particular by hiding behind such categories as "official information" or "lack of public interest". An example of this is the decision in Case 335/13988/17 by the Ordzhonikidze District Court in the lawsuit of the plaintiff to the Zaporizhzhia City Council, regarding the failure to provide the plaintiff as a requester of public information with copies of contracts with the winners in competitive tendering for house managers. The plaintiff who appealed to the Zaporizhzhia City Council for providing him with public information was denied on the grounds that this service required reimbursement of actual expenses and was not paid by the plaintiff. However, the requested information was of public interest, and no charge for copying and printing is required when providing a person with information about oneself and one of public interest. Therefore, the court upheld the plaintiff's claims ${ }^{37}$.

The intensive process of creating modern information legislation led to the emergence of new legal categories and terms. But it is not uncommon for the same terms to appear in different regulatory legal acts with different or ambiguous interpretations ${ }^{38}$.

Due to the fact that various laws and regulations governing public relations with information being the subject were adopted at different times without the agreement of the conceptual apparatus; they have a number of terms that are not correct enough, do not cause appropriate information reflection or do not have a clear definition of content at all. Terminological inaccuracies, different interpretations of similar concepts and categories with

${ }^{36}$ Baranov O. A. (2016) Naprjamy perspektyvnykh doslidzhenj u ghaluzi informacijnogho prava [Areas of Perspective Research in the Field of Information Law]. Information and Law, No. 2 (17), p. 15. (in Ukrainian).

${ }^{37}$ Decision of Ordzhonikidze District Court in Case No. 335/13988/17 2-a/335/58/2018 of March 6, 2018. URL : https://youcontrol.com.ua/catalog/court-document/72697946/. (accessed 25 October 2019).

${ }^{38}$ Baranov O. A. (2016) Naprjamy perspektyvnykh doslidzhenj u ghaluzi informacijnogho prava [Areas of Perspective Research in the Field of Information Law]. Information and Law, No. 2 (17), p. 29. (in Ukrainian). 
the same names and forms lead to their ambiguous understanding and application in practice. For example, with regard to information relations, such terms as "classified information", "secret", "document", "documented information", "property", "possession", "ownership", "intellectual property", "automated system", "subject of public relations", "participants in public relations", "system of information relations", etc. can be mentioned 39 .

The concept of "information about a natural person" requires clarification, which in Article 11 of the Law of Ukraine "On Information" is the same as "personal data". Subject to the laws of the European Union and in accordance with Regulation (EU) 2016/679 of the European Parliament and of the Council of May 04, 2016, "General Data Protection Regulation", the term "personal data" means any information, relating to an identified natural person ("data subject"). It should be emphasized that the EU Regulation uses the unambiguous term "personal data", in contrast to the Law of Ukraine "On Information", where "personal data" is identified with the concept of "information about a natural person" (Art. 11), causing confusion in law enforcement activities. These two categories require differentiation and refinement of content, and information about a person has a broader meaning than personal data.

In addition to the above, there are a number of problematic terminologies and categories of information legislation that need separate scientific development and are not exhausted within the scope of this research.

At the present stage of development of the information society, these aspects determine the theoretical necessity and practical expediency, timely securing the actual categories and terms of information legislation (according to the conditions of time and real needs) which are substantiated by the scientific doctrine of information law.

\section{Development of information support for information relations in SBGS activities}

The intensive use of information systems in the SBGS activities contributes to accelerating not only information processes but also the fulfilment of all tasks assigned to the border guard agency. However, the processing of information in such systems poses an additional threat to its integrity and security. Therefore, at the same time when data is entered, processed, and transmitted in information systems, it is necessary to constantly take measures to secure the content of information in order to

39 Tsymbaliuk V. S., Havlovskyi V. D., Hrytsenko V. V.et al. (2014) Osnovy informacijnogho prava Ukrajiny [Fundamentals of Information Law of Ukraine]. Kyiv: Znannia. p. 110. (in Ukrainian). 
ensure their functioning. Such measures should be comprehensive (legal, organizational, technical, control, prosecution, etc.) and implemented by all officials of the SBGS who have access to the information systems. There are special structural units designated to protect information within the activities of the Main Centre of Communication, Automation and Information Protection in the Administration of the State Border Guard Service of Ukraine where the best experts in the field of information protection are involved; their smooth operation as well as providing opportunities for their professional growth will improve the effectiveness of countering information threats in the research area ${ }^{40}$.

Moreover, the urgent issue today is the introduction of electronic identification of persons, which should be technically embodied and ensured in the practical activities of the SBGS.

Effective information activities of the SBGS depend not only on perfect normative and legal regulation, but also on organizational and methodological support. Its elements are the following: professionalism of the personnel carrying out information activities: knowledge of current information legislation and skills of its application; an appropriate educational program should be mastered within the SBGS; constant improvement of professional skills, abilities to solve complex problems and balance them with the legislation and new emerging threats in the sphere of border guarding; the level of information culture of all personnel and understanding of the integral border guard system by each serviceman influence the positive image of the border guard service; strict adherence to the basic norms, principles and ways of carrying out information activities in the SBGS; providing the management headquarters of the SBGS with timely, reliable, complete, essential, comprehensible information for making sound management decisions in the field of state border security; permanent and continuous implementation of security measures as to information processed in the SBGS information and telecommunication systems; control over compliance with the organization and implementation of security measures as to the information managed by the SBGS.

One of the problems of legal support of management in the SBGS bodies is the ineffective mechanism for providing the SBGS military and civil employees with the necessary legal information for management activities,

40 Kushnir I. P. (2018) Orghanizacijno-pravovi pytannja zabezpechennja zakhystu informaciji $v$ informacijnykh systemakh Derzhavnoji prykordonnoji sluzhby Ukrajiny [Organizational and Legal Issues of Information Security in Information Systems of the State Border Guard Service of Ukraine]. Carpathian Legal Bulletin, No. 3, pp. 81-84. p. 83. (in Ukrainian). 
which is quite topical in the context of development of the law enforcement agency and a shortage of specialists with legal education in the SBGS. One way to solve this problem is proposed by V. L. Zolka: to establish Legal Information Centres at all levels of command; to develop and approve a program for training and retraining of specialists in the field of information and analytical activities with the issues on information law included; make more effective use of existing information and telecommunication systems of the SBGS ${ }^{41}$.

\section{CONCLUSIONS}

Security of the state border of Ukraine is a complex and dynamic sphere of state activities. The border security system is shaped by different tasks and directions in the functioning of the SBGS, which are directly dependent on the border guard agency and (or) national tendency of development. One of the integrated components that depends on state regulation and departmental support is the information component of the SBGS activities, which finds manifestation in information relations.

The research showed that according to the current legislation and specificity of internal activities, the most regulated and considered areas is technical and organizational information support of the SBGS. But information relations also involve communication with the public on the exercise of their information rights in the sphere of border guarding. Thus, a considerable number of manifestations of information relations in the activities of the border guard agency are sufficiently regulated and mainly satisfy the information needs of all subjects of these relations, but there are some issues that need improvement.

The main lever of the problem gravitates toward the absence of a nationwide strategy for the development of the information society (in certain areas only: information security, cyber security, etc.) and systematization of information legislation. Taking into account this and the specifics of activities of the SBGS, the directions have been determined that will help to improve information relations and increase efficiency in the protection of the state border of Ukraine.

These directions are: systematization of information legislation norms; improvement of information law terminology; development of information

${ }^{41}$ Ziolka V. L. (2015) Okhorona nacionaljnykh interesiv Ukrajiny u prykordonnij sferi (administratyvno-pravovyj aspekt) [Protection of Ukraine's National Interests in the Sphere of Border Guarding (Administrative and Legal Aspect)]. Khmelnytskyi: NADPSU. p. 201. (in Ukrainian). 
support for information relations in the SBGS activities; building knowledge and awareness of the SBGS personnel.

Legal regulation of information activities of the SBGS is a system of legal means and methods by which influence on information relations in the field of border security is carried out, the model of behaviour for the realization of a certain type of information activities is formed.

Proper legal regulation and well-established departmental mechanism for organizing information activities in the SBGS will significantly improve the implementation of the state information policy, will promote the efficiency of obtaining, processing and protecting information which is managed by the border guard agency, will provide management activities with more purposefulness, validity, efficiency and effectiveness, comprehensive assurance of information rights of all subjects of information relations and will help to improve the border security and image of the SBGS in general.

\section{SUMMARY}

The article describes the directions for improving information relations in the activities of the SBGS.

Information relations, which are conditioned both by the internal organizational aspects of the information activities of the SBGS and the provision of information rights of citizens (within the competence), require timely coverage and regulation by legal acts, the creation and improvement of clear organizational mechanisms for information support and the adequate state of information security. The issue of improving information relations in the field of SBGS activities is closely related to the expected result, final impact and their impact on the state of border security.

General information tendencies in the development of modern information society, ongoing information war against Ukraine, European integration, change of threats on the state border, the need for increase of efficiency of border security: all these integrating factors conditioned the urgency of working out directions for improvement of information relations in activities of SBGS.

The researched information relations are sufficiently regulated and predominantly meet the information needs of all subjects of these relations, but there are some issues that need improvement. The main problems are caused by the lack of a national strategy for the development of information society and the systematization of information legislation. Taking into account this and the specifics of activities of the SBGS, the directions have been determined that will help to improve information relations and increase efficiency in the protection of the state border of Ukraine. These directions 
are: systematization of information legislation norms; improvement of information law terminology; development of information support of information relations in activities of the SBGS; formation of information knowledge and awareness of personnel of the SBGS.

\section{REFERENCES}

1. Main Directions of Activities and Further Development of SBGS of Ukraine in 2019. URL: dpsu.gov.ua/upload/Haprjami_ДПСУ Optimized.pdf. (accessed 11 October 2019).

2. Kaliuzhnyi R. A., Kushnir I. P. (2015) Pravove zabezpechennja vzajemodiji publichnoji administraciji u prykordonnij sferi [Legal Support for Public Administration Interaction in the Sphere of Border Guarding]. Kyiv: "MP Lesia". (in Ukrainian).

3. Liashuk R. M., Kushnir I. P. (2017) Rezuljtatyvnistj ta efektyvnistj v dijaljnosti orghaniv okhorony derzhavnogho kordonu Ukrajiny [Effectiveness and Efficiency in Activities of the State Border Protection Bodies of Ukraine]. Law and Society, No. 5, pp. 154-159. (in Ukrainian).

4. Kushnir I. P. (2018) Analiz zmistu ponjattja «bezpeka derzhavnogho kordonu» [Content Analysis of "State Border Security" Concept]. Bulletin of the Southern Regional Centre of the National Academy of Law Sciences of Ukraine,. No. 16, pp. 75-81. (in Ukrainian).

5. Maksymenko Yu. Ye. (2014) Normatyvno-pravove reghuljuvannja informacijnykh vidnosyn $v$ Ukrajini: stan ta perspektyvy [Legal Regulation of Information Relations in Ukraine: Status and Prospects]. Legal Bulletin, No. 3, pp. 142-146. (in Ukrainian).

6. Plan of Measures for Realization of the Strategic Course of the State to Acquire Full Membership of Ukraine in the European Union and in the North Atlantic Treaty Organization: by Presidential Decree No. 155/2019 of April 20, 2019. URL: https://www.president.gov.ua/documents/155201926586. (accessed 18 October 2019).

7. On the decision of the National Security and Defence Council of Ukraine of December 29, 2016 "On the Doctrine of Information Security of Ukraine": Presidential Decree of February 25, 2017 No. 47/2017. Official Bulletin of the President of Ukraine. 2017. No. 5. Art. 102.

8. Development of the system of risk analysis in the State Border Guard Service of September 19, 2017. URL : http://dpsu.gov.ua/ua/rozvitoksistemi-analizu-rizikiv-derzhprikordonsluzhbi-/. (accessed 4 October 2019).

9. "On Border Control": Law of Ukraine of November 5, 2009. Bulletin of the Verkhovna Rada of Ukraine. 2010. No. 6. Art. 46. 
10. On Approval of the Procedure for Entering and Leaving Temporarily Occupied Territory of Ukraine (as amended): Resolution of the Cabinet of Ministers of Ukraine of June 4, 2015. No. 367. URL: http://zakon5.rada.gov.ua/laws/show/367-2015-\%D0\%BF. (accessed 20 October 2019).

11. Cyber Security Strategy of Ukraine: Presidential Decree No. 96/2016 of March 15, 2016. Uriadovyi Kurier. 2016. No. 52.

12. Draft Decree of the President of Ukraine on Approval of the Strategy for the Development of Information Space of Ukraine for the Period up to 2020. URL : http://comin.kmu.gov.ua/control/uk/publish/ article?art_id=113102\&cat_id=61025. (accessed 12 October 2019).

13. Kushnir I. P. (2018) Informacijno-pravova dijaljnistj Derzhavnoji prykordonnoji sluzhby Ukrajiny: normatyvno-pravovyj aspekt [Information and Legal Activities of the State Border Guard Service of Ukraine: Regulatory Aspect]. Constitutional and Legal Academic Studies, No. 2, pp. 165-170. (in Ukrainian).

14. On Approval of the State Border Guard Service Development Strategy: Decree of the Cabinet of Ministers of Ukraine of November 23, 2015. No. 1189-r. Uriadovyi Kurier. 2015. No. 220.

15. Shepeta V. O. (2012) Administratyvno-pravovi zasady tekhnichnogho zakhystu informaciji [Administrative and Legal Principles of Technical Protection of Information]. Kyiv: FOP O. P. Lipkan. (in Ukrainian).

16. Aristova I. V. (2000) Derzhavna informacijna polityka: orghanizacijno-pravovi aspekty [State Information Policy: Organizational and Legal Aspects]. Kharkiv: University of Internal Affairs. (in Ukrainian).

17. Maksymenko Yu. Ye. (2007) Teoretyko-pravovi zasady zabezpechennja informacijnoji bezpeky Ukrajiny [Theoretical and Legal Principles for Ensuring Information Security of Ukraine]. Kyiv. (in Ukrainian).

18. Lipkan V. A., Baskakov V. Yu. (2013) Administratyvno-pravovyj rezhym informaciji z obmezhenym dostupom v Ukrajini [Administrative and legal regime of sensitive information in Ukraine]. Kyiv: FOP O. P. Lipkan. (in Ukrainian).

19. Kaliuzhnyi R. A., Kopan O. V., Martseniuk O. H. (2013) Teoretyko-metodologhichni zasady informacijnogho prava Ukrajiny: realizacija prava na informaciju [Theoretical and Methodological Principles of Information Law of Ukraine: Exercise of the Right to Information]. Kyiv: "MP Lesia" (in Ukrainian). 
20. Krestovska N. M., Matvieieva L. H. (2015) Teorija derzhavy $i$ prava. Pidruchnyk. Praktykum. Testy [The Theory of State and Law. Textbook. Case Study. Tests: textbook]. Kyiv: Yurinkom Inter. (in Ukrainian).

21. Lipkan V. A., Cherepovskyi K. P. (2014) Inkorporacija informacijnogho zakonodavstva Ukrajiny [Incorporation of Information Legislation of Ukraine]. Kyiv: FOP O. P. Lipkan. (in Ukrainian).

22. Lipkan V. A., Zalizniak V. A. (2012) Systematyzacija informacijnogho zakonodavstva Ukrajiny [Systematization of Information Legislation of Ukraine]. Kyiv: FOP O. P. Lipkan. (in Ukrainian).

23. Shkarupa V., Tsymbaliuk V. (2006) Zastosuvannja polozhenj prava shhodo formuvannja osnov teoriji informacijnogho prava [Application of Legal Provisions to Form the Basis of Information Law Theory]. Legal Informatics. No. 3 (11). p. 44-51. (in Ukrainian).

24. Bieliakov K. I. (2009) Orghanizacijno-pravove ta naukove zabezpechennja informatyzaciji $v$ Ukrajini: problemy teoriji ta praktyky [Organizational, Legal and Scientific Support of Informatization in Ukraine: Problems of Theory and Practice]. Kyiv. (in Ukrainian).

25. Lytvyn N. A. (2018) Administratyvno-pravove zabezpechennja informacijnoji dijaljnosti orghaniv Derzhavnoji fiskaljnoji sluzhby Ukrajiny [Administrative and Legal Support of Information Activities of Bodies of the State Fiscal Service of Ukraine]. Irpin. (in Ukrainian).

26. Zhanhozha R. (2000) Do pytannja rozshyrennja informacijnogho prostoru Ukrajiny [On the Issue of Expansion of the Information Space of Ukraine]. Strategic Panorama. No. 3, pp. 203-206. (in Ukrainian).

27. Baranov O. A. (2016) Naprjamy perspektyvnykh doslidzhenj $u$ ghaluzi informacijnogho prava [Areas of Perspective Research in the Field of Information Law]. Information and Law, No. 2 (17), p. 15-31. (in Ukrainian).

28. Decision of Ordzhonikidze District Court in Case No. 335/13988/17 2-a/335/58/2018 of March 6, 2018. URL : https://youcontrol.com.ua/catalog/court-document/72697946/. (accessed 25 October 2019).

29. Tsymbaliuk V. S., Havlovskyi V. D., Hrytsenko V. V.et al. (2014) Osnovy informacijnogho prava Ukrajiny [Fundamentals of Information Law of Ukraine]. Kyiv: Znannia. (in Ukrainian).

30. Kushnir I. P. (2018) Orghanizacijno-pravovi pytannja zabezpechennja zakhystu informaciji $v$ informacijnykh systemakh Derzhavnoji prykordonnoji sluzhby Ukrajiny [Organizational and Legal Issues of Information Security in Information Systems of the State Border 
Guard Service of Ukraine]. Carpathian Legal Bulletin, No. 3, pp. 81-84. (in Ukrainian).

31. Ziolka V. L. (2015) Okhorona nacionaljnykh interesiv Ukrajiny $u$ prykordonnij sferi (administratyvno-pravovyj aspekt) [Protection of Ukraine's National Interests in the Sphere of Border Guarding (Administrative and Legal Aspect)]. Khmelnytskyi: NADPSU. (in Ukrainian).

Information about the author: Iryna Kushnir, Candidate of Law Sciences (Ph.D), doctoral candidate of higher doctorate of the National Academy of the State Border Guard Service of Ukraine named after Bohdan Khmelnytskyi, 46 Shevechenko str. Khmelnitskyi, Ukraine ORCID ID: orcid.org/0000-0003-0286-7591 